\title{
OKOS MOBILITÁS
}

\section{SMART MOBILITY}

\author{
Tokody Dániel
}

Óbudai Egyetem Biztonságtudományi Doktori Iskola, 1081 Budapest, Népszínház utca8,tokodi.daniel@bgok.hu

\begin{abstract}
One of the main characteristics of smart city is smart mobility. Therefore, our study focusses on some questions of smart mobility, especially on the development of intelligent railway. We examine the role of intelligent management systems in the improvement of railway safety. Thus, this article deals with the reasons for the establishment of the intelligence-based smart city as well as one of its substantial element; smart mobility. The main scope of this article is the technical viability of intelligent railway systems.
\end{abstract}

Keywords: Innovation, Smart city, Intelligent Transportation Systems, Smart mobility

\section{Összefoglalás}

Az okos városban létrejövő folyamatok egyik fontos eleme az okos mobilitás. A témán belül egy speciális területtel foglalkozunk ez pedig az intelligens vasúti rendszer kialakítása. A cikkben egyszerre foglalkozunk majd az innováció mozgatta okos város létrehozásának okaival és annak lényeges elemével, az okos mobilitással.

Kulcsszavak: innováció, okos város, intelligens közlekedési rendszerek, okos mobilitás

\section{Bevezetés}

A címben megfogalmazott téma kutatásának tartalma, aktualitása a világon ma élő közel 7,5 milliárd [1] ember szemszögéből egyaránt fontos. A United Nations szerint 2014-re az emberiség több mint fele városokban élt. A városiasodás üteme az eltelt évtizedek alatt rendületlen módon folytatódott. Mára a globális problémák elodázhatatlanok. Milyen megoldással álltak elő a tudósok? Ez a megoldás lehet a fenntartatható okos város koncepciója. 2014 októberében az International Telecommunication Union tanulmányában foglalta össze a Smart és fenntartható városokkal kapcsolatos fogalmakat. Szerintük „A fenntartatható okos város egy olyan innovatív város, ami az infokommunikációs technológiákkal és más ehhez szükséges eszközökkel javítja a városlakók életminőségét, a város müködésének és szolgáltatásainak hatékonyságát. Mindezzel megteremti a települések versenyképességét. Azáltal, hogy biztosítja a jelen és jövő generációi számára a városi élet gazdasági, szociális és környezeti szempontú szükségleteit." [2] $\mathrm{Az}$ okos mobilitás az okos város hat alappillérének egyike Cohen szerint [3]. A téma aktualitását mutatja, hogy az okos várossal kapcsolatosan több szabvány is napvilágot látott már az elmúlt években. A szabványok mennyiségéből látható, hogy 
még csak a szabványosítás elején járnak a szakértők. Nem így van ez az intelligens közlekedési rendszerek kapcsán. Ahol 2016-ban 210 db ISO szabványról tudunk. Ebböl kifolyólag is következtethetünk az ilyen rendszerek komplexitására. A szabványok tartalmi köre a vasúti közlekedés szempontjából minimális, a szintbeni közút-vasút kereszteződések témakörében merül ki.[4]

\section{Az okos mobilitás vasúti aspektusainak áttekintése}

A mobilitás az emberek mozgásának, utazásának kifejezésére használt fogalom. A mobilitás növekedése arányos a közlekedés technológiai fejletségével. A hagyományos közlekedési rendszerek továbbfejlesztésével létrehozhatók az intelligens közlekedési rendszerek idegen szóval ITS rendszerek (Intelligent Transportation System). Az ITS a rendszereket sokan csak a közúti alkalmazások kapcsán hangsúlyozzák így van ez az ISO 204-es Technikai Bizottság szabványosító munkája kapcsán is. Ugyanakkor például az European Telecommunications Standards Institute egyértelmüen nyilvánvalóvá teszi, hogy a közlekedés összes ágazatának (pl.: közúti jármürendszerek, vasúti rendszerek, légi és vízi rendszerek) szerepe van az intelligens közlekedési rendszerek létrehozásában. [5] Franklin és mások szerint az intelligens közlekedési rendszerek olyan információs, kommunikációs és elektronikai technológiai rendszerek alkalmazását jelenti, amely javítja a közlekedés biztonságát, növeli annak hatékonyságát és csökkenti a közlekedésnek a társadalomra és a környezetre ható káros hatásait. [6] Cikkében az intelligens közúti közlekedéssel kapcsolatosan említi a forgalomirányító központokat, az utazási információs rendszereket, időjárással kapcsolatos rendszereket, az intelligens jármü rendszereket, a balesetekre figyelmeztető és az ezeket megelőző rendszereket. [6] $\mathrm{Az}$ intelligens vasúti rendszerek kapcsán rendszerelemként említi a forgalomirányító rendszereket (pl.: ERTMS - European Railway Traffic Management Systems), az utazási információs rendszereket és az elektronikus jegyrendszereket. [6] Ugyanakkor, ha engedünk az elképzelésnek, amit a kooperatív rendszerek jelentenek mind az okos városban mind pedig a közlekedés minden területén akkor belátható, hogy a közúton alkalmazott technológiák átültethetők a kötöttpályás közlekedésre. Mi több a szükségszerü kapcsolatok létrejöttének fontos része a technológiák szimbiotikus együttműködése, azonos alapokon való müködése, azok kompatibilitásának megvalósítása. A korábbi szakirodalom igen szükszavúan fogalmaz, vasúti témában szinte csak azt említi, amit az európai irányelvek ide sorolnak. Példának okáért a közúti közlekedésben használt intelligens jármürendszereknek a vasút esetében is lehet létjogosultsága van. Ebböl következik, hogy a vasúti intelligens közlekedési rendszer számos elemmel bővülhet a hagyományoshoz képest. Korábbi cikkeinkben már említettük, hogy szükséges a vasúti rendszer intelligenssé tétele. De miért van erre konkrétan szükség? Hosszútávon szempont lehet például a vasúti biztonság növelése, a vasúti közlekedés hatékonyságának javítása. Vasúti környezetben a biztonság fogalmát az MSZ EN 50126 szabvány így határozza meg: „Az elfogadhatatlan károsodási kockázatoktól való mentesség.” [7] Miért nem elegendőek a hagyományos rendszerek a biztonság további fokozására? A válasz nagyon egyszerủ és ennek okait az aktuális vasúti baleseti statisztikában kereshetjük. 2013-ban UIC szerint 1873 szignifikáns baleset történt. [8] Ez bizony igen jelentős. A balesetek mennyiségének csökkentésére 
szükség van. Sajnos az utóbbi évtizedekben szignifikáns változás ennek kapcsán nem történt ezért újabb módszerek alkalmazásával kell élnünk. A kutatásunk célja a biztonság növelése intelligens rendszerek használatával. Az emberiség régi vágya, hogy az általa alkotott rendszerek valamilyen emberhez hasonló tulajdonságokkal rendelkezzenek ilyen tulajdonság az intelligencia is. Hogyan kell értelmezni az intelligencia fogalmát, például az vasúti irányító rendszerek kapcsán? „Az intelligencia megjelenésére (folyamat)irányító rendszerekben akkor van szükség, ha az irányítási feladatok legalább egyike intelligens problémamegoldást igényel. Ebben az esetben intelligens irányító rendszerről beszélhetünk." [9] A vasúti rendszer számos területén ma még nélkülözhetetlen az emberi intelligencia. A közeljövőben első lépésként az emberi munkavégzést nagyban támogató intelligens rendszerek térnyerése valószínü. $\mathrm{Az}$ évszázad végére elérhetjük, hogy a közlekedési rendszerekben az autonóm müködés mindennapivá válik.

\section{Következtetések}

A vasúti közlekedés biztonsága ez idáig a vasúti pálya és annak közvetlen környezetére korlátozódott. A közlekedő vonat biztonságos útját kellett biztosítani a vasúti környezetben, vagyis, hogy pl.: ne történjen ütközés, kisiklás, utolérés stb. Ma leginkább a vasúti járművek közötti interakciókra koncentrálunk, a környezetet pedig csak tájékoztatjuk a vasúti jármüvek közlekedéséről. Ezzel szemben más a világ szemlélete. A közlekedési rendszerek együttműködése egyre fontososabbá válik a biztonság, a gyorsaság a gazdaságosság egyszerre történő megvalósítása kapcsán. Ki hozza meg a döntést arról, hogy egy közúti jármünek az vasúti átjárónál meg kell-e állni? Egyszerü, annak vezetője. Viszont ma már valóság az autonóm (de hívhatnánk: vezetőnélküli, önvezető vagy robot) autók megléte. [10] [11] Ahogyan az elektromos hajtású autók úgy ezek az eszközök is előbb utóbb piaci pozícióba fognak kerülni. Kötött pályán az automatizáltság tekintetében a metró fejlesztések elérték a GoA4 szintet (Grade of Automation), ami a vonatműködés tekintetében Unattended Train Operation vagyis felügyelet nélküli teljesen automatikus jármü futást jelent. Azaz nem, hogy vezető, de még vonatkísérő sincs a fedélzeten. [12] Az UITP szerint ezt a legmagasabb automatizáltságot az Automatic Train Operation és Automatic Train Control rendszerek együttes működésével valósítják meg. [12] A világon egyes források szerint $74 \mathrm{db}$ GoA4 szintű metró van és ebből egy a budapesti 4-es vonal. Mindezek ellenére a nagyvasúton még mindig küzdelmek árán biztosítjuk a biztonságot. Ez a mindenki által ismert biztonság az, amit egy figyelmetlen autós másodpercek alatt tehet semmissé. Nagyon messze vagyunk még a fenti két példától. A nagyvasút esetében megoldás lehet többek között az intelligens közlekedési rendszerek megvalósítása. Ditmeyer a Michigan Egyetem adjunktusa már 2010-ben arról ír, hogy az Egyesült Államokban 2000-ben megfogalmazódott az intelligens vasút víziója. Munkájában 32 technológiát illetve rendszert sorol fel a hálózat centrikus vasúti müködés kapcsán, melynek alapját az intelligens vasúti rendszert megvalósító elemek teremtik meg. Mint például az automatikus RFID alapú vasúti jármű és kocsi azonosítására szolgáló rendszer, vagy a vasúti pálya menti érzékelő rendszerek, az intelligens időjáráselőrejelző rendszer, energia menedzsment rendszerek, az intelligens közúti-vasúti kereszteződésekben használt rendszerek. Úgy képzeli el a vasúti rendszer müködését, mint amiben a különböző rendszerek és folyamtok interoperábilis módon rendszerek rendszereként (system of 
systems) müködnek együtt. [13] Az intelligens vasúti rendszer megvalósítására számos technológia nyújthat lehetőséget. Ilyen megoldás lehet a jármü-jármü kommunikáció megvalósítása a teljes közlekedési struktúrában vagy például az érzékelő rendszerek nagyobb mérvü elterjesztése az okos város teljes vertikumában. A rendszerekben meglévő adatok, információk megszerzése, feldolgozása és felhasználása a jövőben kiemelkedő fontossággal fog bírni egy intelligens autonóm rendszer kialakítása kapcsán. És végezetül felhívjuk a figyelmet arra, hogy a lokális intelligens megoldások csak akkor fogják szolgálni az okos város azon belül is az okos mobilitás céljait, ha a különféle rendszerekben keletkező információ megosztásra és felhasználásra kerül a kapcsolódó kooperatív struktúrákban. Így segítve a rendszerek közötti szinergikus együttműködést.

\section{Szakirodalmi hivatkozások}

[1] KSHl: A világ népessége kontinensek szerint 1950-2100, ENSZ adatok https://www.ksh.hu/interaktiv/grafikonok/vila g_nepessege.html (Letöltve: 2016.01.08.)

[2] ITU, Smart sustainable cities: An analysis of definitions, p. 13. https://www.itu.int/en/ITU-

T/focusgroups/ssc/Documents/Approved_Del iverables/TR-Definitions.docx (Letöltve: 2016.01.08.)

[3] B. Cohen, The Smartest Cities In The World 2015: Methodology, http://www.fastcoexist.com/3038818/thesmartest-cities-in-the-world-2015methodology (Letöltve: 2016.01.10.)

[4] B. Williams: ITS Standards. p.14. Norwood. 2008. ISBN-13: 978-1-59693-291-3

[5] ETSI: ITS http://www.etsi.org/technologiesclusters/technologies/intelligent-transport (Letöltve: 2016.01.11.)

[6] F. Franklin et al., Rail infrastructure, ITS and access charges, Research in Transportation Economics, Volume 41, Issue 1, May 2013, pp.31-42, ISSN 0739-8859, http://dx.doi.org/10.1016/j.retrec.2012.10.004 http://www.sciencedirect.com/science/article/ pii/S0739885912001588

(Letöltve:

2016.01.10.)

[7] MSZ EN 50126:2001. Vasúti alkalmazások. A megbízhatóság, az üzemkészség, a karbantarthatóság és a biztonság (RAMS) előírása és bizonyítása. p.12

[8] IUR: Safety Platform, Safety Database Report 2014 - Significant Accidents 2013, ISBN 978-2-7461-2325-0, http://old.uic.org/download.php/publication/5 45c_pub.pdf (Letöltve: 2016.01.10.)

[9] R. Lakner et al. Intelligens Irányító Rendszerek, Egyetemi tananyag. p.10. 2011. http://oszkdk.oszk.hu/storage/00/00/58/37/dd/ 1/Lakner_Hangos_Gerzson_Intell_ir_rendsz. pdf (Letöltve: $201 \overline{6} .01 .11$.)

[10] Stanford, Volkswagen team up to create automotive research lab. http://news.stanford.edu/news/2007/novembe r28/volks-112807.html (Letöltve: 2016.01.10.)

[11] Automated Driving Applications and Technologies for Intelligent Vehicles: System Classification and Glossary 06.02.2015 http://www.adaptive-

ip.eu/index.php/deliverables_papers.html?file $=$ files/adaptive/content/downloads/Deliverabl es $\% 20 \% 26 \% 20$ papers/AdaptIVe-SP2-v12DL-D2.1\%20System\%20Classification.pdf (Letöltve: 2016.01.10.)

[12] UITP: Metro automation: facts, figures and trends.

http://www.uitp.org/sites/default/files/Metro $\% 20$ automation $\% 20$ -

$\% 20$ facts\%20and\%20figures.pdf (Letöltve: 2016.01.10.)

[13] S. R. Ditmeyer.: Network - Centric Railway Operations Utilizing Intelligent Railway Systems. Journal of Transportation Law, Logistics and Policy Third Quarter 2010 Volume 77, Number 3. http://www.transportation.northwestern.edu/d ocs/2011/2011.03.15.Ditmeyer_Paper.pdf (Letöltve: 2016.01.12.) 